\title{
STUDY OF APPROACHES, METHODS, SOURCES AND INTERPRETATION INSTRUMENTS OF MULLA SADRA
}

\author{
Moh. Nadhir Mu'ammar \\ Pascasarjana UIN Sunan Gunung Djati Bandung \\ Email : Mnadhir111@gmail.com
}

\begin{abstract}
This research is carried out on some uniqueness found in the interpretation of the Al-Qur'an by Mulla Sadra, including: he is a philosopher who is the foremost in interpreting the Al-Qur'an and productive writers who have produced many works. In the hands of Mulla Sadra, the synthesis of the three Islamic intellectual schools, namely Sufi makrifat, philosophy or theosophy, and Shiite theology was finally reached, and directly reflected in the field of esoteric interpretation of the Al-Qur'an. Based on the uniqueness, the author is interested in examining it with the title: "Mulla Sadra's Interpretation Methodology (Study of Approaches, Methods, Sources and Instruments of Interpretation)". The purpose of this study is to find out and explore the methodology of the interpretation of Al-Quran Mulla Sadra, as well as describe how the approach, methods, sources and instruments of interpretation of the Al-Quran that he initiated. And to find out and criticize the application of the interpretation methodology of Al-Quran Mulla Sadra in its interpretation product. This type of research is a library research based on the book of Tafsir al-Qur'an al-Karim as a primary data source. Based on this research, we can draw the conclusion that Sadra's work is a combination of approaches and interpretive methods that have developed in the Islamic world. The advantage is that it combines two approaches, namely $\mathrm{f}$ irfani and philosophy. This is then considered a bridge from the different interpretive traditions in the Islamic world.
\end{abstract}

Keyword: Interpretation, Methodology, Mulla Sadra

\section{INTRODUCTION}

Viewed from the historical perspective of the development of science, which, according to Thomas Kuhn takes place dialectically and revolutionarily, the interpretation of that period was put forward using the paradigm. The paradigm is a fundamental view of the subject matter (subject matter) of the object being studied (A. Putra, 2014). In the study of interpretation, the object is the Al-Qur'an. So the interpretation paradigm is a fundamental view of the Al-Qur'an, regarding what should be studied. Interpreters of the Al-Qur'an must use a paradigm, because it inherently exists in the theory of interpretation which - consciously or unconsciously - is used in the preparation of interpretations (Abha, 2014).

The Al-Qur'an has been interpreted with the methods of tahlili, ijmali, muqarin, and maudu'i through approaches or patterns that span: from fiqh, philosophical, literary and social, Sufi, theological to science (Abdullah, 2014). According to Aksin Wijaya, there are two forms of popular interpretation of the Al-Qur'an. First, how to interpret linguistically. This interpretation method seeks to reveal the meaning of the Al-Qur'an based on linguistic analysis, both concerning grammar (naḥw), morphology (șarf), and semantics (ma'ani). Second, how to interpret that reveals the social and cultural historical conditions (contextual). This method seeks to explain the meaning and content of the teachings of the Al-Qur'an by understanding the socio-historical context, both when the Al-Qur'an came down (nuzul) and the sociohistorical context when applied (tatbiq) (Wijaya, 2009).

* Copyright (c) 2019 Moh. Nadhir Mu'ammar

This work is licensed under a Creative Commons Attribution-ShareAlike 4.0 International License. 
In general, it can be explained that the historical process has given birth to two models of approach in understanding the Al-Qur'an. First, an approach that uses analytical tools derived from Islamic disciplines, which are commonly used in the theological, fiqh and Sufism traditions. Second, an approach that uses devices from outside the Islamic discipline used in philosophy (Wijaya, 2009). The choice of this approach model is based on the belief of some Muslims regarding the dichotomy of science, namely sharia (religion) and philosophy.

Islamic philosophy was developed by Muslim thinkers based on Al-Quran values and studies of Greek and Syrian works or texts translated into Arabic. The result is the amalgamation or integration of various ideas - especially from Pythagorean theory, Platonism, Aristotelianism, Neoplatonism, Hermeticism and some of Stoicism - into the view of the Al-Qur'an which, in turn, forms a new perspective (Nasr, 2002b). Various philosophical theories developed, starting with Peripatetic Philosophy (Masysya'iyyah) and Isma'iliyyah thought from the 9th century AD onwards. This early period gave birth to many prominent philosophers, such as al-Kindi, al-Farabi, Ibn Sina (Avicenna) and Ibn Rusyd (Averroes), whose influence on the Western Middle Ages was enormous.

Sadra's interpretation works can be categorized into two types, namely interpretation of the surah and interpretation of the verse. Some surahs of the Al-Qur'an that Sadra has commented on include: alFatihah, al-Baqarah, al-Sajdah, Ya Sin, al-Ḥadid, al-Waqi'ah, al-Jumu'ah, al-Ṭariq, al-A'la and al -Zilzal. As for the verse category, there are three, namely: ayat al-kursi, ayat al-nur and QS al-Naml [27]: 88 (Mohammed Rustom, 2009)

Besides Tafsir al-Qur'an al-Karim, which amounts to 7 volumes (Mohammed Rustom, 2009), Sadra has written specifically several theoretical works related to the Al-Qur'an, namely: Mafatih al-Gaib, Mutasyabihat al-Qur'an and Asrar al-Ayat wa Anwar al-Bayyinat (Sadra, 2002). Mafatih al-Gaib contains an introduction to the interpretation of the Al-Qur'an which talks about the methods and principles of the ta'wil. In addition, this important work also includes ethical values, metaphysics and spiritual messages of the Al-Qur'an. Mutasyabihat al-Qur'an is a short treatise that outlines some homonym verses of the AlQur'an (mutasyabihat), along with Sadra's interpretation methodology related to these verses. While Asrar al-Ayat wa Anwar al-Bayyinat presents the mystery or esoteric meanings of the verses of the AlQur'an relating to God, beings (nature), humans and the ultimate goal of humans (Hamdani, 2016).

As has been agreed that the whole roots of Islamic cosmkualology are found in the Al-Qur'an. Mulla Sadra thinks that the Al-Qur'an is the same as the Being itself. Being, like the Al-Qur'an, has letters (huruf) which are "keys to the unseen world" and from the combination of letters, verses are formed and verses are composed of surahs (suwar) of the Scriptures. Furthermore, from the combination of the surah produced "Book of Being" (Kitab al-Wujud) which manifests itself in two ways: as al-furqan or differentiator, and al-Qur'an or reading. The furqan aspect of the holy book is the macrocosm with all its diversity, while the Quranic aspect is the spiritual reality and human archetypes, commonly called universal or perfect humans (al-insan al-kamil) (Nasr, 2002a).

No philosopher in the history of Islamic philosophy has paid great attention to the Al-Qur'an as a source of philosophical and theosophical knowledge, and has written many interpretations of the AlQur'an as Sadrā did. The interpretations of Sadra's Al-Quran are a continuation of his "transcendent theosophy" and his "transcendent theosophy" are the result of the development of the inner meaning of the Qur'an as Sadra understands, which incessantly necessitates harmony between revelation (al-wahy) and intellect or reason (al-'aql). He asserted that the intellect, from which reason is a reflection of the mental level, is the inner prophet of humanity which manifests itself only in people who are in the language of the Al-Qur'an: "profound knowledge" (al-rasikhun fi al-'ilm). 
It is precisely at this point that the offer of Sadra's interpretation reveals different characteristics from the studies of Muslim scholars (read: mufasir or theosophists-interpreters) before and after. This door is what the author wants to enter further in this study. Moreover, in addition to the uniqueness and idiosyncratic factors related to Sadra that have been described above, studies on Sadra in the realm of the Al-Qur'an and its interpretation are still very rarely carried out compared to efforts to explore aspects of philosophical thought.

\section{METHODOLOGY}

This study uses a qualitative method (Sugiyono, 2013). The qualitative method is described as a research procedure that produces descriptive data in the form of written or oral words from people and observable behavior. Qualitative research conducts research in a natural setting or in the context of an entity (Raco, 2018).

\section{RESULT AND DISCUSSION}

\section{Application of Mulla Sadra's Interpretation Methodology in its Interpretation Products}

Al-Hikmah al-Muta'aliyah ('peak wisdom' or someone who translates it as 'Overcoming Wisdom'), as we have previously mentioned, was born from the synthesis of Sadra's attempts at various Islamic intellectual discourses previously in space and level different (Arifin, 2012). The success of the synthesis certainly has a reverse effect on the Islamic treasury, both the concepts put forward by Sadra become rational arguments or new truths that bring new concepts of understanding to the Islamic treasury. In this regard, Sadra is the culmination of the development of irfan, kalam and philosophy of Islam after Ibn Rushd, and also the culmination of the deductive-illuminative-religious methodology.

One of the most classical Islamic treasures is the interpretation of the word of Allah which is contained in the holy book of the Al-Qur'an. To see the influence of the concept of the epistemology of Ittihad al-Aqil wa Ma'qul in the interpretation of the Al-Qur'an, let us examine Sadra's interpretation of verses related to science (QS al-Baqarah [2]: 31).

This verse according to Sadra tells the glory of humans because of the knowledge of the Names they have. The giving of this knowledge is not based on the learning process and it also does not relate to lafazh which shows meaning, but the transmission of knowledge about the nature of the existence and entities of all things. This process is also referred to as the tajalli form of the Name, which is the meaning of objectivity in the occultation of the existence of God which then emanates at the lowest levels of existence. Sadra revealed:

"And He explained to them (the Angel) the glory of mankind over them, that is because of their knowledge of the knowledge of the Names ... And clearly that the purpose of teaching the Names (Ta'lim al-Asma ') is not merely teaching thematic lafazh on the basis of expressing meanings as in the definitions of lafazh, but the transmission of knowledge to the nature (existence) and entities of all things (Sadra, 1972)".

Whereas Sadra's expression which explains the meaning of the names referred to, is as follows:

"That the essence of Himself is based on the nature of all the attributes or tajalli of all forms of tajalli called the Names for Arif (Philosophers / Expertise of Wisdom) and the Names revealed are the Names of all Names and are the objective meanings of objects in the occultation (maqam) of the occult. the existence of Allah, which identifies His form and emanation through it (Names) (Sadra, 1972)". 
For Sadra, the transmission of Allah's knowledge to humans is an existential transmission because the entire universe emanates from Himself, thus the nature of the gift of knowledge is actually the process of emanating the Names of Allah in human beings. The concept of giving knowledge that is explained in the interpretation of the above verse clearly reflects his view of the unity between subjects, objects and relations between the two in humans. And in his conclusion to this verse, Sadra explained that all of nature is a manifestation of the Names of Allah that are emitted in humans.

The existence of something is sometimes formed by (takwin) like the creation of the body and the like with it (ISMAIL, RANI, HUSIN, \& KIRAM, 2018), in the first way of growth. Sometimes also with the creation (ibda') such as the creation of spirits and the like, with the second growth. Allah Almighty is the creator of creatures and everything, the owner of kingdoms and malacca, the owner of the world and the hereafter. When Allah gives a signal by mentioning the qualities of rahman and rahim, after the proposition of the specificity of praise, then He has gathered all the qualities of perfection. He explained the way of creation in the world with His word; الْعَالَمبن رَبّ which implies that the natural form of the world is formed through stages, gradually. He also explained the other chronology of creation in His Word: مَالِلِكِ يَوم الَّيَِّ because the Real Owner is He who has the essence of everything, and is not forgetting of it at all. Then something comes from God. This is what means ibda', while the first means takwin (Sadra, 1972).

The End Times is also called yaum al-din because here it means that something arrives at the end / peak / end which is a substance, and the fruit which occupies a reward, reward for charity. As the word of God, "On this day all souls are rewarded according to their deeds" (Surah al-Mu'min [40]: 17). From this it is said that the world is a place of charity, and the hereafter is a place of retribution, as recorded in His word elsewhere (QS Jonah [10]: 30). Because the first realm is the realm of movements, and alternating and the other is the place of birth and turning away which is the land of residence and a place of goodness and vices.

From here Abu 'Ali al-Jaba'i said" Allah wants yaum al-din which is the day of vengeance on religion. And Muhammad ibn Ka'b said: "What Allah wants is a day that is of no use except religion (Sadra, 1972)."

Finally, as an example of another Sadra Al-Qur'an hermeneutics, the author will briefly present an esoteric interpretation of the 'verse of light' presented by Sadra. The verse in question is 'ayat al-nur' (QS al-Nur [24]: 35) which reads as follows:

"Allah (the giver) of light (to) heaven and earth. His parable of light, like a hole that is not translucent, in which there is a large lamp. The lamp in the glass tube (and) the glass tube is like a sparkling star, lit with oil from a blessed tree, (ie) an olive tree that grows neither in the east nor in the west, whose oil (only) is almost illuminating, although not touched by fire. The light above the light (in layers), Allah gives guidance to His light for the person He wants, and Allah makes parables for humans. And Allah is All-Knowing everything. "

\section{Textual Considerations}

The word 'light' (nur) in the above verse, according to Sadra, is not the subject of an 'accidental' which consists of collections as understood by dialectical philologists and theologians. (A. A. Putra, 2019). Instead this 'light' is one of the names of Allah, and He is the giver of lights.

'Light' in its complete sense has many meanings according to most scholars. Some are homonymous, or vague (have two or more meanings), some have literal meanings, others are metaphors, such as: sunlight, moonlight, light, mind light, faith light, godly light, red pomegranate light (ruby), golden light, turquoise (stone) light and others. 
In the perspective of illuminated metaphysics experts such as Syihab al-Din al-Suhrawardi (d. 587/1191) and his followers, light is "simple self-manifestations that bring things towards manifestation." This reality changes based on its intensity and weakness, and the highest level is Light above light (nur 'ala nur) (Sadra, 1972).

\section{Sufi interpretation and Sadra's comments}

In Sadra's observations, some early Sufi masters interpreted this verse based on the meaning given by the Prophet Muhammad. It was narrated, he noted, that the Prophet was asked, "What is 'light'? He answered, "[light is Divine Guidance]. When light penetrates into the heart of a believer, the heart 'expands' and becomes 'empty'. " The Prophet was again asked, "What is the sign (light)?", He replied, "Apart from worldly [aspirations], directing attention to the eternal world, and being ready to accept death before coming".

Then Sadra stated that the word 'light' in the verse al-nur means Divine Guidance that penetrates the heart of a believer. Like the 'Pelita' (Misbah) which is enclosed in the 'Glass Tube' (Zujajah), in the same way the human biological self (nafs hayawani) is enclosed in the 'recess' of his heart. The 'lamp' is lit by 'Oil', which means the form of travelers is illuminated by 'oil' from various intuitive circumstances and stations. The situation here, as Sadra observed, is the result of honest relationships in the world, worship, and obedience to God (Sadra, 1972).

\section{Philosophical interpretation and Sadra's commentary}

Sadra notes that philosophers such as Ibn Sina (d. 429/1037) and Nasr al-Din al-Tusi (d. 673/1274) interpret this verse as follows:

'Niche' (Misykat) means the intellect of [human] material which in itself is 'dark', but can receive intellectual light in varying degrees according to its readiness. Glass Tube means intellect in habitus. [This is the next level of rational soul in ascending order] At this level, it is transparent by itself [like a 'glass tube'], and is very sensitive to light (intellectual) as is its 'shining star' (kaukabun durriyun) to physical light. The Olive Tree (Syajarah Zaitunah) means [the next higher level of the rational soul which is] a cogitative and contemplative faculty. This faculty [at this level] is ready to simply accept [intellectual] light but after exerting all energy. He was 'blessed' because he was able to produce definitions of various things, and improve demonstrative evidence. [The cogitative faculty] is 'not in the east nor in the west' (la syarqiyyah wa la garbiyyah). That means the cognitive power that reaches universal meanings, mental ideas, and understandable propositions is not part of animal power when the light (intellectual) is completely gone (with the symbol 'west' - the place of the sunset), nor is it part of a pure active intellect [with the symbol 'east' - the place of sunrise]. 'Oil' (Olive) means the intuitive power of [intellect]. The 'Pelita' symbolizes the 'holy power' [of the Tenth Intellect] where the potential (human) intellect becomes the actual intellect. 'Light upon light' (nur 'ala nur) means' acquired intellect' (lam tamsashu nar / acquired intellect). This interpretation according to Sadra shows various levels of rational souls in ascending order, namely: material intellect, intellect in habitus, actual intellect, and acquired intellect (Mohammed Rustom, 2009).

\section{Interpretation according to the School of Philosophy of Illumination}

The following interpretation according to Sadra is given by Sufis who experience 'illumination' (isyraq) divinity, and 'spiritual taste'. This is based on the mystical experience of the Illumination philosophers. The meaning of 'light', in Sadra's perspective, is shown in the narrative of the Prophet's night ascent (mi'raj). After his mi'raj experience, the Prophet was asked by his companions if he saw Allah, and 
if so, what He wanted. The Prophet answered, "[Yes]. God is light. It is impossible (for anyone) to see Him with physical eyes."

Sadra commented: The Prophet used the symbol 'light' for Allah, implying that the Divine Reality is the reality of the manifested self, which brings everything towards manifestation. Followers of the Illumination philosophy use the term 'Light on Light' (nur al-anwar) for Allah. This light changes in perfection and imperfection, greatness and weakness. The most perfect light is the Light of God. After that there are higher lights which are divided into intellectual lights and soul lights. Then follow the lower lights which are divided into the light of the stars and the light of the Elements.

\section{Sadra's interpretation of the 'Verse of Light'.}

Sadra elaborates: Light and Existence or Being are the same reality. The symbol 'Pelita' (Misbah) means God's real Light on everything. 'Recess' (Misykat) means lesser being in this world. The 'Glass Tube' (Zujajah) is a symbol for a higher being [ie, intellect and other worldly souls]. 'Oil' (Olive) means 'breath of the Compassionate' (nafs al-rahman), which is the Absolute Being that spreads and extends from the Almighty (al-Haqq) to beings. It also means illuminating emanations on beings called 'the most holy emanations' (al-faid al-aqdas). The 'blessed tree' (syajarah mubarakah) is a symbol for the 'being' or 'light' that comes from the 'holiest emanation'. This accentuates the appearance or light above the various arrangements in the world according to their acceptance and readiness. Just like a tree that has many branches and leaves, the "holiest emanation" also has many dimensions. This manasi 'neither in the east nor in the west' (la syarqiyyah wa la garbiyyah). That is, emanation is not related to mere Being in the condition of 'Oneness', or the essence of multiplicity. 'Light above light' (nur 'ala nur) means, Higher Need Light which gives emanation to lower light. 'God guides His light to the person He wants' means, He manifests Himself life to whomever He wants. Through this manifestation something comes into the light of being from the darkness of non-existence (Sadra, 1972).

\section{Sadra's guidance for the seekers of light}

"Know, 0 my beloved, the level of light is unknown except by Light. On the other hand, each degree is only known by these types of levels. Mindful light is felt by intelligent light, mental light by mental light, and intellectual light by intellectual light. Namely, the light of the stars felt by the light of the eyes, the rational light felt by the senses, etc. ".

"Know, $\mathrm{O}$ travelers, please contemplate, reflect on, and take advantage of what is written in these lines. Open your eyes wide; rest assured that the 'straight path' (sirat al-mustaqim) and the road [towards] Allah are not on earth or in the sky, not on land or in the sea, not in the world or in the Other, but in the traveler, who travels with him and in it towards his Lord (Sadra, 1972)."

Sadra's interpretation differs in approach and attention from the main Shi'ite interpretations. The language of the Al-Qur'an - according to Sadra - is 'open at its highest level', borrowing the words of P. Ricoeur, which can provide many interpretations according to the level of the form of a believer. Therefore the language of the Al-Qur'an is basically polysemy. This polysemy is horizontal just like vertical nature. The deepest meanings, the levels of meaning are all inherent in the concrete words of the Word of God at the sensor level and the Word (kalam) of God at the highest non-material and supra-rational levels.

The contents of Sadra's interpretation are basically philosophical and esoteric-gnostic. If grouped, the central issues that emerge from their interpretations include moral, philosophical, esoteric and gnostic. To the extent that morality can be seen as related to law, and law with the state, an argument might be structured to claim in particular the political significance of all the parts he uses as moral issues. These 
themes implicitly convey the message that if each individual takes the responsibility morally and spiritually to improve himself based on his understanding of the Al-Qur'an, then the whole society can be improved, but, explicitly, Sadra rarely relates to the basic nature of government or behavior country.

Interpretation of this genre, in the writer's opinion, is very unique in Shia religious literature. Sadra's interpretation has had a profound impact on subsequent Shi'ite interpretations, including the most recent being al-Mizan by 'Allamah Muhammad Husain Țabațaba'i (d. 1978 CE).

\section{CONCLUSION}

Sadra's work in general is a scientific process with pre-existing interpretation principles. However, there are also several approaches which he developed himself. Furthermore, these works are a synthesis of previous works that combine all existing interpretive models. This is also supported by the principle of studying the theory of science, which includes a study of the nature of science, sources, knowledge, methods and also the test of truth. Sources of Interpretation. Sadra often includes studies from interpretations, grammar, language and qira'ah. He quoted the works of the previous commentators' scholars. What he quoted is not limited to Shi'ite interpretations, but includes all existing interpretations. The interpretation of the Al-Qur'an which he cites is largely the interpretation of the figure of Mu'tazilah al-Zamakhsyari, Shi'a commentator al-Qummi and al-Tabarasi and the theologians of the Ash'ariyah Fakhr al-Din al-Razi; Sadra notes the interpretation of the Prophet and Shiite Imams, Sufis and Gnostics ('urafa') and then gives their deepest meaning. In some cases, a number of readings (qira'ah) of the Al-Qur'an are also included, especially readings from Kufa and Basrah such as al-Nakha'i, Qutadah, al-Hasan al-Basri, alKisa'i, and others. Apart from interpretive and grammatical sources, Sadra also gives meaning according to his knowledge, mystical experience and epistemology: he interprets the Al-Qur'an with the Al-Qur'an. Methods. The main principle in its interpretive activities, Sadra prefers the methodology adopted by alrasikhun fi al-ilm, and those chosen by God to reveal the various truths, spiritual meanings, mysteries and guidance of God in the revelations and secrets of ta'wil.

As a manifestation of his methodology that combines all the existing methodologies of earlier commentaries or in his day, Sadra in his interpretation uses a more technical working principle. He combines philological approaches, linguistic, interpretations and philosophy together in explaining verses. Sadra usually begins his interpretation with the philological treatment of the verse spoken of. He often gives several opinions that differ from one word or phrase of the Al-Qur'an derived from linguists, and leave it at that, even quoting contradictory opinions. Next he tries to achieve harmonization in differences of opinion or shows that one opinion must be more trusted than another. At the same time, Sadra noted the interpretation of the verse or word spoken of by theologians, philosophers, commentators and others; he accepts their interpretation or criticizes it, and even gives his own interpretation. The most decisive and distinguishing feature in Sadra's Interpretation is his philosophical meditation on the Al-Qur'an, and also his opinion that the meaning of a particular verse is revealed to him through intellectual inspiration from God's Throne, or there is magical (Divine illumination). Therefore he repeatedly stated that "what is written by esoteric interpreters, is not true knowledge of the Qur'an, or the gnosis of God's revelation in the true sense. That sort of thing is related to philology, grammar and dialectics, and only touches the outer shell.

\section{REFERENCES}

Abdullah, D. (2014). Musyawarah Dalam Al-Quran (Suatu Kajian Tafsir Tematik). Al Daulah: Jurnal Hukum Pidana Dan Ketatanegaraan, 3(2), 242-253. 
Abha, M. M. (2014). Kajian Kritis Atas Kitab Al-Tafsir Al-Tawhidi Karya Hasan Al-Turabi. Jurnal Studi Ilmu-Ilmu Al-Qur'an Dan Hadis, 15(1), 39-60.

Arifin, S. (2012). Kontruksi Wacana Pluralisme Agama Di Indonesia. Jurnal Humanity, 5(1).

Hamdani, F. (2016). Teori Interpretasi Nasr Hamid Abu Zayd. Farabi: Journal Of Ushuluddin \& Islamic Thought, 13(1), 30-45.

Ismail, N., Rani, M. Z. A., Husin, F., \& Kiram, N. H. M. (2018). Islam Dalam Persembahan Dikir AlBurdah Oleh Pertubuhan Badan Kesenian Dan Kebudayaan, Kampung Sessang, Sarawak. Jurnal Melayu, 2(17).

Mohammed Rustom. (2009). Qur'anic Exegesis In Later Islamic Philosophy: Mulla Sadra's Tafsir Surat Al-Fatiha. Toronto: University Of Toronto.

Nasr, S. H. (2002a). Mulla Sadra: Ajaran-Ajarannya". Ensiklopedi Tematis Filsafat I.

Nasr, S. H. (2002b). The Heart Of Islam: Enduring Values For Humanity. New York: Harpercollins.

Putra, A. (2014). Khazanah Tafsir Melayu (Studi Kitab Tafsir Tarjuman Al-Mustafid Karya Abd Rauf Al-Sinkili). Syahadah: Jurnal Ilmu Al-Qur'an Dan Keislaman, 2(2).

Putra, A. A. (2019). Vertikalitas Historis Sebagai Basis Filsafat Sejarah Dalam Perspektif Mistisisme Ibnu Arabi. Jurnal Al-Aqidah, 11(1), 1-30.

Raco, J. (2018). Metode Penelitian Kualitatif: Jenis, Karakteristik Dan Keunggulannya.

Sadra, M. (1972). Mutasyabihat Al-Qur'an" Dalam Śalaś Rasa'il Al-Falsafiyah. Mashhad: Danesgahe Mashhad.

Sadra, M. (2002). Mafatih Al-Gaib (Muhammad K). Beirut: Mu’assasat Al-Ta'Rikh Al-'Arabi.

Sugiyono. (2013). Metode Penelitian Pendidikan Pendekatan Kauntitatif, Kualitatif Dan R\&D. Bandung: Alfabeta.

Wijaya, A. (2009). Teori Interpretasi Al-Quran Ibn Rusyd: Kritik Ideologis-Hermeneutis. Yogyakarta: Lkis. 